\title{
Antarctic research hit by crisis
}

\section{BAS counts the cost of island invasion}

The present dispute between the United Kingdom and Argentina over the Falkland Islands has raised fears about the future of the British Antarctic Survey. But according to the survey's director, Dr Dick Laws, the invasion of the islands by Argentina came too late to have much effect on this season's work, with bases on the Antarctic continent already preparing for the long isolation imposed by the austral winter.

The British Antarctic Survey depends on the Falkland Islands to maintain contact with its research stations. The US National Science Foundation has agreed to provide a temporary commercial relay service via its base on the Antarctic peninsula, Palmer, stressing that it would only pass on messages of a scientific nature and would not handle those dealing with "political matters". In the long term, though, the communications problem could be resolved by setting up a new relay station, probably at the existing British base on Signy Island, in the South Orkneys. The Falklands are also used by the survey as a supply base, and although not indispensable, loss of those facilities would undoubtedly add to the difficulty and cost of operations. Alternative refuelling facilities within easy reach of the British bases are in the Magellan Straits, but so far Chile has not offered use of these.

Direct confrontation between the survey and the Argentinians has so far only occurred on South Georgia, where the commander of Grytviken base is also the senior representative of the Falkland Islands government. Grytviken, base for 26 of the survey's scientists at the time, had earlier been the scene of fighting between Royal Marines and Argentinian forces, although it is not yet known whether the base suffered any damage. Operations at Grytviken were in any case due to be reduced as from this month following budget cuts, despite pressure to maintain a British presence there. South Georgia has recently become a centre for work on krill, whose study as the dominant planktonic organism in the Southern Ocean is important for the exploitation of the Antarctic seas.

These problems come at the end of a troubled season for the British Antarctic Survey. In November the survey lost its two aircraft in hurricane-force winds at Rothera Station, resulting in the cancellation of virtually all Earth science projects, which rely heavily on air support of field parties. Damage to a De Havilland Twin Otter aircraft and the research vessel

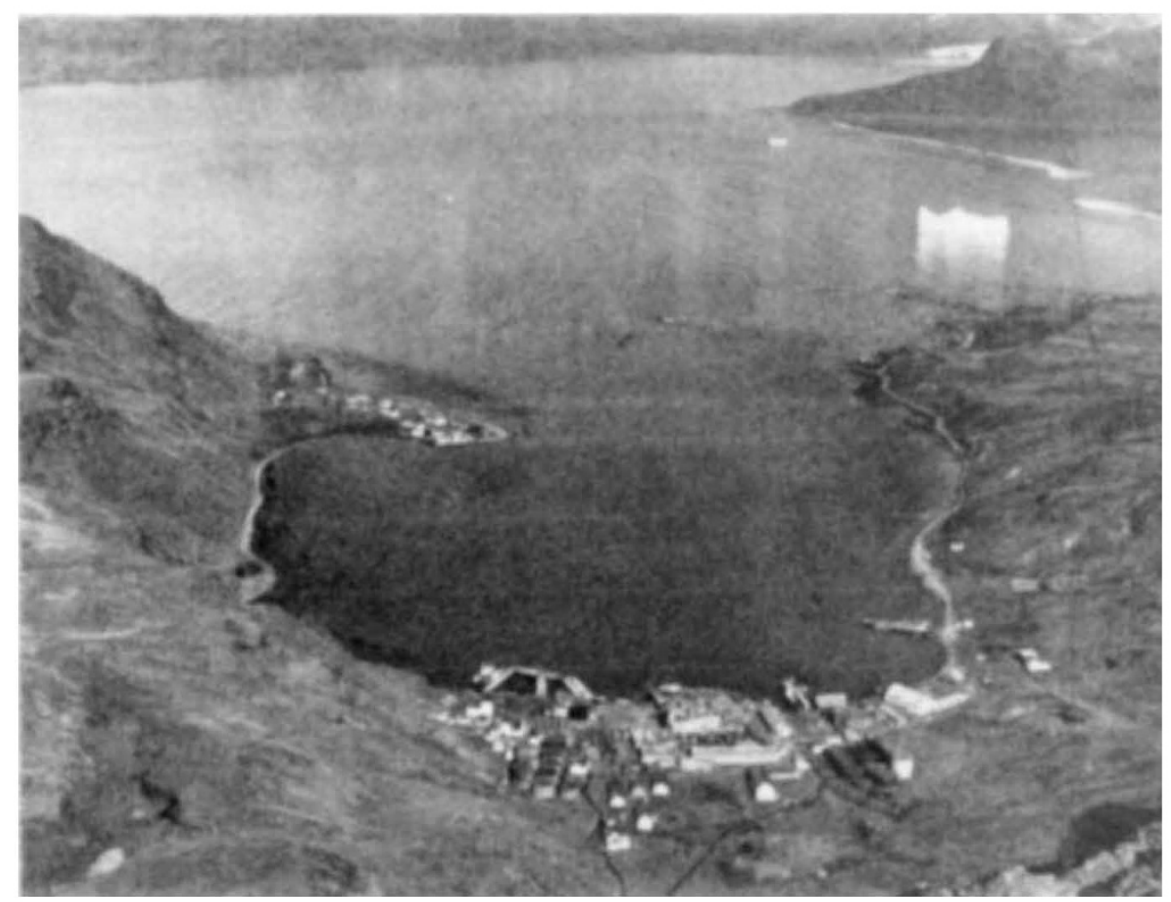

South Georgia, showing the British Antarctic Survey's base at Grytviken (left) and the former whaling station (foreground).

John Biscoe the previous year had already meant abandoning that season's marine biological work, and cutting short other research programmes.

However, the future for what is widely acknowledged to be one of the most costeffective research organizations operating in the Antarctic, is not entirely bleak. The Natural Environment Research Council, who provide the survey's annual funds of $£ 5.6$ million, have provided an additional $£ 1.8$ million for the purchase of two new aircraft, and $£ 1.3$ million for the rebuilding of an important station at Halley Bay, now nearly ten years old. Collaborative research with West Germany is another route that the survey has been exploring to keep within its budget.

The Argentinian action will probably not immediately affect the activities of other nations in the area, which include the United States, the Soviet Union, Poland, Chile and Argentina itself, as none-of these rely upon the Falklands for their communications or supplies. Although Argentina's own research efforts have been extremely limited, it is at present collaborating with the French in glaciological work, and plans exist to site a ground station for the first European Space Agency remote sensing satellite to be put into polar orbit, at the Argentinian base of Marambio.

Clearly the Falk lands invasion is going to affect Argentina's standing amongst the Antarctic Treaty nations, due to meet in Hobart in two months' time to discuss the future exploitation of a region with a hitherto exemplary history of peace and international cooperation. David Millar

\section{Graduatestudents on shorter lease}

British postgraduates take too long to complete their $\mathrm{PhD}$ theses, according to the report of a working party on postgraduate education published last week. Blame is laid primarily on the universities, although the research councils are also criticized for not taking matters more firmly in hand.

The working party, set up in 1979 by the Advisory Board for the Research Councils, found wide discrepancies in $\mathrm{PhD}$ submission rates between universities and between the natural and social sciences. Its recommendation that the research councils award postgraduate quotas on the basis of a department's past completion record is being taken up by the Science and Engin- eering Research Council (SERC) in deciding quotas for 1982-83. SERC has also published a pecking order of universities based on PhD completion success which is intended to shame universities into remedial action.

The working party was set up two years ago under the chairmanship of Sir Peter Swinnerton-Dyer, then vice-chancellor of the University of Cambridge, to advise on postgraduate education policy. It has managed to comply with its remit to assess the ways in which research councils make awards to universities and particular disciplines and whether sufficient postgraduates of the right quality are produced. But the task of determining 